Article

\title{
Utilization of Several Industrial Wastes as Raw Material for Calcium Sulfoaluminate Cement
}

\author{
Phongthorn Julphunthong ${ }^{1}$ and Panuwat Joyklad ${ }^{2, *}$ \\ 1 Department of Civil Engineering, Faculty of Engineering, Naresuan University, Phitsanulok 65000, Thailand \\ 2 Department of Civil and Environmental Engineering, Faculty of Engineering, Srinakharinwirot University, \\ Nakhon Nayok 26120, Thailand \\ * Correspondence: panuwatj@g.swu.ac.th; Tel.: +66-8137-99758
}

Received: 9 September 2019; Accepted: 10 October 2019; Published: 12 October 2019

\begin{abstract}
The aim of this research was to study the production of calcium sulfoaluminate (CSA) cement from several industrial waste materials including with marble dust waste, flue gas desulfurization gypsum, ceramics dust waste, and napier grass ash. The chemical composition, microstructure, and phase composition of raw materials were examined using energy dispersive X-ray fluorescence (EDXRF), scanning electron microscopy (SEM), and X-ray diffraction (XRD), respectively. All raw wastes were analyzed using their chemical composition to assign proportion for raw mixture. The raw mixture is calcined at controlled calcination temperatures ranging from $1200{ }^{\circ} \mathrm{C}$ to $1300{ }^{\circ} \mathrm{C}$ for $30 \mathrm{~min}$. Subsequently, with analysis, their phase composition is calculated by the Rietveld refinement technique. The results suggested that phase composition of clinker calcined at $1250{ }^{\circ} \mathrm{C}$ shows the closest composition when compared to target phases, and was selected to prepare CSA cement. The FTIR analysis was performed to study the hydration processes of CSA cement. The Ordinary Portland cement (OPC) based with adding CSA cement between $20 \mathrm{wt} . \%$ and $40 \mathrm{wt} . \%$ were investigated for the effect of CSA cement fraction on water requirement, setting times and compressive strength. The results showed that rapid setting and high early strength can be achieved by the addition of 20-40 wt.\% CSA cement to OPC.
\end{abstract}

Keywords: calcium sulfoaluminate cement; industrial wastes; ye'elimite; Rietveld refinement technique; compressive strength

\section{Introduction}

The utilization of by-products or industrial wastes as additions to Ordinary Portland Cement (OPC) is a well-known technique to reduce the $\mathrm{CO}_{2}$ emissions associated with the energy-intensive manufacture of cement [1]. An alternative way to reduce the embodied $\mathrm{CO}_{2}\left(\mathrm{eCO}_{2}\right)$ from $\mathrm{OPC}$ production is the use of a non-PC based system as a binding ingredient. Calcium sulfoaluminate cement (CSA cement) is one such alternative binder which lowers $\mathrm{eCO}_{2}$ emission compared to OPC. CSA cement was originally developed in China in the 1970s and has been used since then [2]. Gartner [3] studied the $\mathrm{eCO}_{2}$ emissions of individual cement components, and estimated that the $\mathrm{eCO}_{2}$ emission from producing a typical CSA cement consisting of ye'elimite, belite and, aluminoferrite is approximately $600 \mathrm{~kg} / \mathrm{t}$. This represents an $\mathrm{eCO}_{2}$ reduction of approximately $35 \%$ compared to OPC [1]. The total reduction of $\mathrm{eCO}_{2}$ emission is the result of three main causes: Reduction of burning temperature by approximately $100-150{ }^{\circ} \mathrm{C}$, reduction of energy consumption during the grinding process due to easier grindability, and reduction of $\mathrm{eCO}_{2}$ due to a lower fraction of $\mathrm{CaCO}_{3}$ in the raw materials.

CSA cements all include ye'elimite $\left(\mathrm{C}_{4} \mathrm{~A}_{3} \$\right)$, belite $\left(\mathrm{C}_{2} \mathrm{~S}\right)$, and aluminoferrite $\left(\mathrm{C}_{4} \mathrm{AF}\right)$ phases, which are in different proportions depending on the application [4-6]. CSA cements have demonstrated 
rapid setting, high early-age strength, self-stressing, and shrinkage compensating properties due to the fast reacting $\mathrm{C}_{4} \mathrm{~A}_{3} \$$ and the expansive nature of ettringite [7-19]. In field practices, CSA cements have been used mainly in pre-cast concrete applications and repair applications due to their high early-age strength development. However, industrial scale production and usage of CSA cements is still limited in China [20]. The main factors holding back widespread production of CSA cement is its relatively high cost and the limited availability of the required raw materials. Natural deposits of calcium and silicon oxides are plentiful throughout most of the world, making it possible to produce Ordinary Portland cement cheaply in most areas using local materials. However, CSA cements produced for commercial use contain large amounts of $\mathrm{C}_{4} \mathrm{~A}_{3} \$$, which requires a higher amount of aluminum oxide than in Ordinary Portland cement. The most commonly used source of aluminum is bauxite deposits which are not widespread. Additionally, the extracted alumina can be expensive.

Thailand has begun to transform its economy from agriculture to export-oriented manufacturing, while integrating key manufacturing production into the regional value chain. This transformation has led to the production of various types of industrial wastes in large amounts, which inevitably become an environmental problem. In this study, a variety of industrial waste materials including marble dust waste, flue gas desulfurization gypsum, ceramics dust waste, and napier grass ash were selected to use as raw materials in the synthesis of CSA cement. These raw ingredients were proportioned according to the phase composition calculated from a modified Bogue's equation. The finished CSA cements synthesized from waste materials were then further studied to verify their actual phase composition and hydration processes. Finally, Ordinary Portland cement-CSA cement blends with various proportions were investigated in order to determine the influences of CSA cement content on water requirement, setting time, and compressive strength of the cement paste.

\section{Materials and Methods}

\subsection{Raw Materials and Sample Preparation for CSA Clinker}

The industrial waste materials selected for synthesis of the CSA clinker were provided from several sources. Marble dust waste (MDW) was provided in the form of a wet slurry from a marble factory in Kampheang Phet Province, Thailand. Flue gas desulfurized gypsum (FGDG) was procured from Mae Moh Power Plant in Lampang Province, Thailand. Ceramic dust waste (CDW), which is produced during the final polishing process of ceramic tiles, was supplied from Ceramic Chemical Refractory, Lampang Province, Thailand. Napier grass ash (NGA) was collected from Vithai Biopower Plant, Uthai Tanee Province, Thailand. All waste materials were dried in an oven at $80^{\circ} \mathrm{C}$ for $24 \mathrm{~h}$ and then sieved through $150 \mu \mathrm{m}$ mesh. The mineralogical compositions and microstructure of these waste materials were investigated using X-ray diffraction (XRD) and scanning electron microscopy (SEM) images, respectively. Finally, chemical compositions of the four materials were analyzed using energy dispersive X-ray fluorescence (EDXRF). Data on the chemical compositions of the waste materials was used to estimate the proportions of raw materials for the mixture using the modified Bogue's equation calculation [21] for the targets $\mathrm{C}_{4} \mathrm{~A}_{3} \$$ ( $\left.\sim 50 \mathrm{wt} . \%\right), \mathrm{C}_{2} \mathrm{~S}(\sim 40 \mathrm{wt.} \%)$, and $\mathrm{C}_{4} \mathrm{AF}(\sim 10 \mathrm{wt} . \%)$. Analytical-grade $\mathrm{Al}_{2} \mathrm{O}_{3}$ was added as a raw material (25 wt.\%) to obtain the desired composition. $\mathrm{CaF}_{2}$ was added to the starting materials $(0.8 \mathrm{wt} . \%)$ to accelerate and enhance their reactivity [22].

The calculated amounts of starting materials were weighed and mixed in a ball-mill with ethanol for $24 \mathrm{~h}$. The suspension was dried using a hot plate, ground using an agate mortar, and then sieved into a fine powder. The powder was molded into spherical samples ( 10 $\mathrm{g}$ and $10 \mathrm{~mm}$ diameter), and the samples were placed in $\mathrm{Pt} / \mathrm{Rh}$ crucibles and fired in an electric furnace. The firing process consisted of two steps. In the first step, the samples were calcined at $800{ }^{\circ} \mathrm{C}$ for $30 \mathrm{~min}$ to dehydrate and calcine the raw ingredients. In the second step, the samples were heated up to three different temperatures $\left(1200^{\circ} \mathrm{C}, 1250^{\circ} \mathrm{C}\right.$, and $1300^{\circ} \mathrm{C}$, respectively) and fired for $30 \mathrm{~min}$. In all cases the heating rate of the furnace was $5{ }^{\circ} \mathrm{C} / \mathrm{min}$. After the second step, the CSA clinker was immediately removed from the furnace and rapidly cooled. 


\subsection{Analytical Methods}

\subsubsection{Energy Dispersive X-ray Fluorescence (EDXRF)}

The energy dispersive X-ray fluorescence (EDXRF) analytical technique was employed to determine the chemical composition of the raw materials and synthesized CSA clinker. This investigation utilized the interaction of $X$-rays with each material to determine each sample's elemental composition using a Horiba XGT-5200 X-ray analytical microscope.

\subsubsection{X-ray Diffraction (XRD)}

The XRD analysis was carried out in order to determine the mineralogical phase of the raw materials, the synthesized clinker, and the OPC. The dried samples were then ground into a fine powder and sieved through 150-mesh (opening of $104 \mu \mathrm{m}$ ). The analysis was performed with a PAnalytical $X^{\prime}$ pert Pro powder diffractometer with $\mathrm{Cu}-\mathrm{K} \alpha$ radiation $(1.54187 \AA, 40 \mathrm{~mA}, 40 \mathrm{kV})$ as the radiation source. The powder patterns were gathered in the $2 \theta$ range of $10-60^{\circ}$. Rietveld refinement quantitative phase analyses of the CSA clinker and the OPC were done using DIFFRAC.SUITE TOPAS V.5.0 software. The refined parameters included phase scale factors, background coefficients, zero-shift error, lattice parameters, peak shape parameters, and preferred orientation, if needed. As for reliability of the data, with the software's "goodness of fit" setting fixed to $<4$, the fitted curve matched well with the raw data [23-25].

\subsubsection{Scanning Electron Microscopy (SEM)}

Scanning electron microscopy (JEOL JSM 5910 LV), was used to observe the morphology and the particle size of the raw materials. The samples were finely grinded into powders with an agate mortar and sieved through the $150 \mu \mathrm{m}$-opening mesh. Prepared powders were coated with a thin layer of gold to promote electrical conductivity further to microstructure characterization.

\subsubsection{Fourier-transform Infrared Spectroscopy (FTIR)}

The Fourier-transform infrared (FTIR) analysis was performed using a Perkin Elmer FTIR System Spectrum X spectrometer in the range of $400-4000 \mathrm{~cm}^{-1}$ with spectral resolution of $1 \mathrm{~cm}^{-1}$. This analytical technique was used to identify the functional group signals of the anhydrous cement and hydrated pastes. The specimens were ground to a fine powder using a mortar and pestle. For hydrated pastes, the samples were washed with acetone to remove water in an effort to mitigate the hydration reaction. After washing with acetone, the samples were thoroughly dried in an oven at $45{ }^{\circ} \mathrm{C}$ for an hour.

\subsubsection{Water Requirement, Setting Time and Compressive Strength of Various CSA Blends}

Currently, most countries use expanding CSA-based ternary blends consisting of CSA clinker, added gypsum, and OPC [26,27]. The current study also used this combination, based on the novel CSA clinker which was prepared from industrial wastes. In order to test various blends containing CSA clinker, six systems were selected to test the engineering properties of their cement pastes. The first system is $100 \%$ OPC, and this system is referred to as OPC. The remaining five systems are all CSA/OPC blends consisting of CSA clinker initially mixed with $20 \mathrm{wt} . \%$ of natural gypsum [28] (abbreviated as CSA cement), followed by addition of an amount of OPC to yield a net CSA cement content of $20 \%, 25 \%, 30 \%, 35 \%$ and $40 \%$ by weight. Thus, the five blended systems are referred to as CSA20, CSA25, CSA30, CSA35, and CSA40, reflecting their CSA cement content by weight (Table 1). The amount of water required by each test system for normal consistency of its cement paste was determined using the ASTM C187 test [29]. The initial and final setting times of the cement pastes were found by performing the ASTM C191 test [30]. For the compressive strength test, each fresh paste was cast into $25 \mathrm{~mm}$ acrylic cube molds according to the method of Rungchet et al. [31] with a w/b 
ratio of 0.34 . The specimens were demolded at the age of $3 \mathrm{~h}$ and cured in a moisture-controlled room at $20^{\circ} \mathrm{C}$ with $95 \%$ R.H. Their compressive strength was tested at the curing periods of $6,12,24,72,168$, 336 and $672 \mathrm{~h}$.

Table 1. Mix ratios of CSA/OPC blends for water requirement, setting times, and compressive strength tests.

\begin{tabular}{ccccc}
\hline Sample & OPC (wt.\%) & CSA Clinker (wt.\%) & Gypsum (wt.\%) & CSA Cement (wt.\%) \\
\hline OPC & 100 & - & - & - \\
CSA20 & 80 & 16 & 4 & 20 \\
CSA25 & 75 & 20 & 5 & 25 \\
CSA30 & 70 & 24 & 6 & 30 \\
CSA35 & 65 & 28 & 7 & 35 \\
CSA40 & 60 & 32 & 8 & 40 \\
\hline
\end{tabular}

\section{Results and Discussion}

\subsection{Characterization of Raw Materials}

Figure 1 shows the XRD patterns of the industrial waste materials which were selected as starting materials. The main mineral component of MDW is calcite $\left(\mathrm{CaCO}_{3}\right)$, while that of FGDG is gypsum $\left(\mathrm{CaSO}_{4} \cdot 2 \mathrm{H}_{2} \mathrm{O}\right)$. The XRD patterns of NGA reveal an amorphous phase. CDW has two crystalline phases: Quartz $\left(\mathrm{SiO}_{2}\right)$ and kaolinite $\left(\mathrm{Al}_{2} \mathrm{Si}_{2} \mathrm{O}_{5}(\mathrm{OH})_{4}\right)$. The results of the EDXRF chemical composition tests agreed with and confirmed the mineralogical analysis results from the XRD patterns, as shown in Table 2.

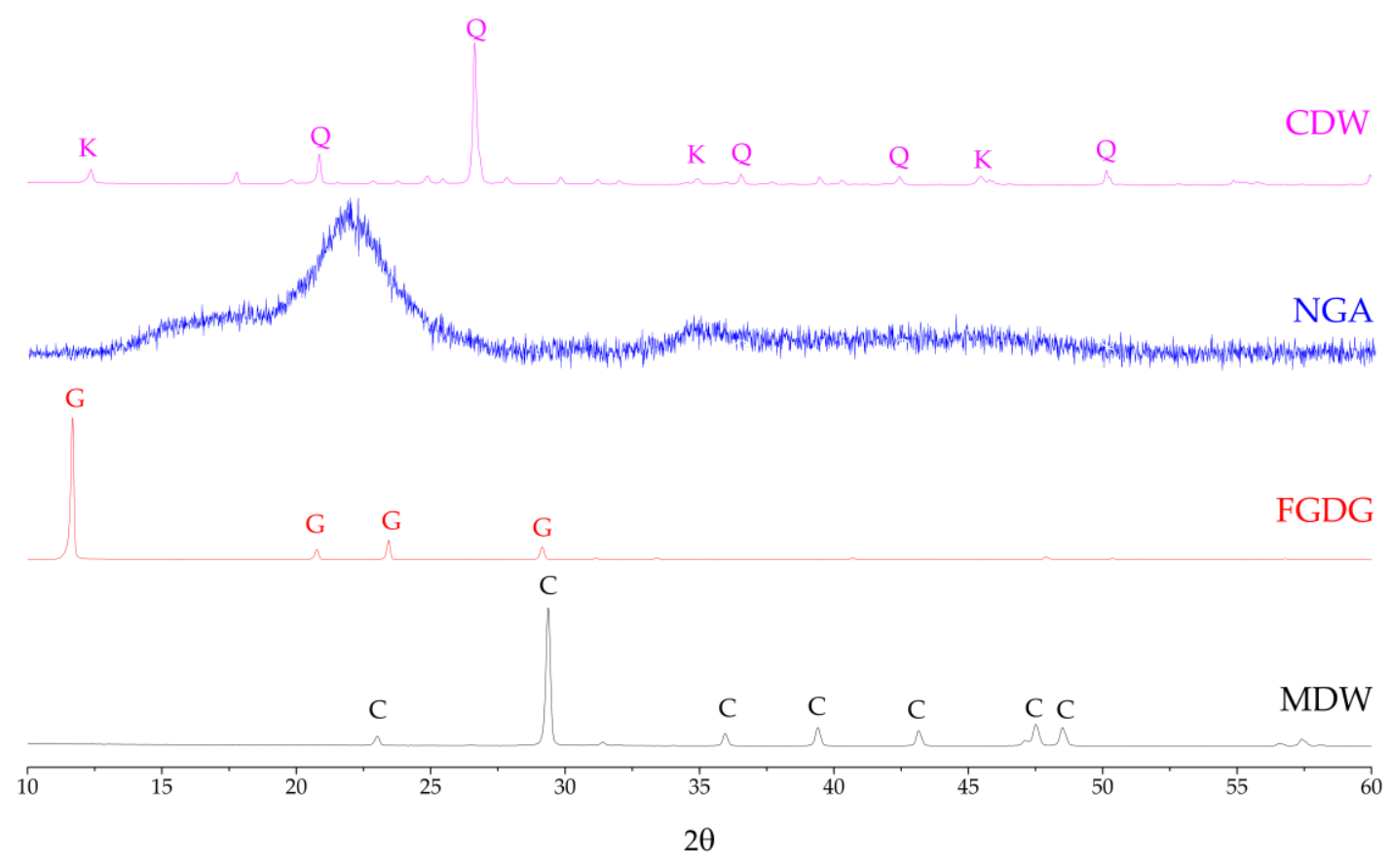

Figure 1. X-ray diffraction patterns of the four waste materials. $C=$ calcite, $G=$ gypsum, $Q=$ quartz, and $\mathrm{K}=$ kaolinite.

The SEM micrographs of MDW, FGDG, NGA and CDW powders are shown in Figure 2. CDW shows an irregular shape and a slight agglomerated form. A well-grade particle size distribution was observed with a range of lower than $1 \mu \mathrm{m}$ to higher than $20 \mu \mathrm{m}$. For FGDG powders, a plate-like shape with medium agglomeration was observed. The agglomerate sizes vary from $10 \mu \mathrm{m}$ to $30 \mu \mathrm{m}$ but the majority of them vary in size from $15 \mu \mathrm{m}$ to $20 \mu \mathrm{m}$. For NGA, a porous agglomerated form 
powders of about 5-15 $\mu \mathrm{m}$ size are seen with close to spherical shapes. CDW powders exhibited an irregular shape with a gap-grade of particle size distribution. They consist of the large particles with irregular shape and small particles with porous agglomerated form.

Table 2. Chemical composition of the four industrial waste materials used, laboratory reagent grade $\mathrm{Al}_{2} \mathrm{O}_{3}$ powder, target chemical composition of the raw mixture, and measured chemical composition of the clinker fired at $1250^{\circ} \mathrm{C}$.

\begin{tabular}{|c|c|c|c|c|c|c|c|c|}
\hline $\begin{array}{c}\text { Raw } \\
\text { Materials }\end{array}$ & $\begin{array}{l}\text { Mix Proportions } \\
\text { (wt.\%.) }\end{array}$ & $\mathrm{CaO}$ & $\mathrm{SiO}_{2}$ & $\mathrm{Al}_{2} \mathrm{O}_{3}$ & $\mathrm{Fe}_{2} \mathrm{O}_{3}$ & $\mathrm{SO}_{3}$ & $\mathrm{~K}_{2} \mathrm{O}$ & $\mathrm{P}_{2} \mathrm{O}_{5}$ \\
\hline MDW & 41 & 100 & - & - & - & - & - & - \\
\hline NGA & 10 & 3.58 & 69.92 & 8.42 & 7.74 & - & 7.23 & 1.18 \\
\hline CDW & 10 & - & 68.65 & 15.62 & 5.37 & - & 9.62 & - \\
\hline FGDG & 14 & 49.34 & - & - & - & 49.25 & - & 1.28 \\
\hline $\mathrm{Al}_{2} \mathrm{O}_{3}$ & 25 & - & - & 100 & - & - & - & - \\
\hline \multicolumn{2}{|c|}{$\begin{array}{l}\text { Target chemical composition } \\
\text { of raw mixture }\end{array}$} & 48.57 & 13.94 & 27.48 & 1.32 & 6.72 & 1.70 & 0.33 \\
\hline \multicolumn{2}{|c|}{$\begin{array}{l}\text { Measured chemical composition of } \\
\text { calcined clinker at } 1250{ }^{\circ} \mathrm{C}\end{array}$} & 49.13 & 14.20 & 24.83 & 2.14 & 7.01 & 0.43 & 0.09 \\
\hline
\end{tabular}
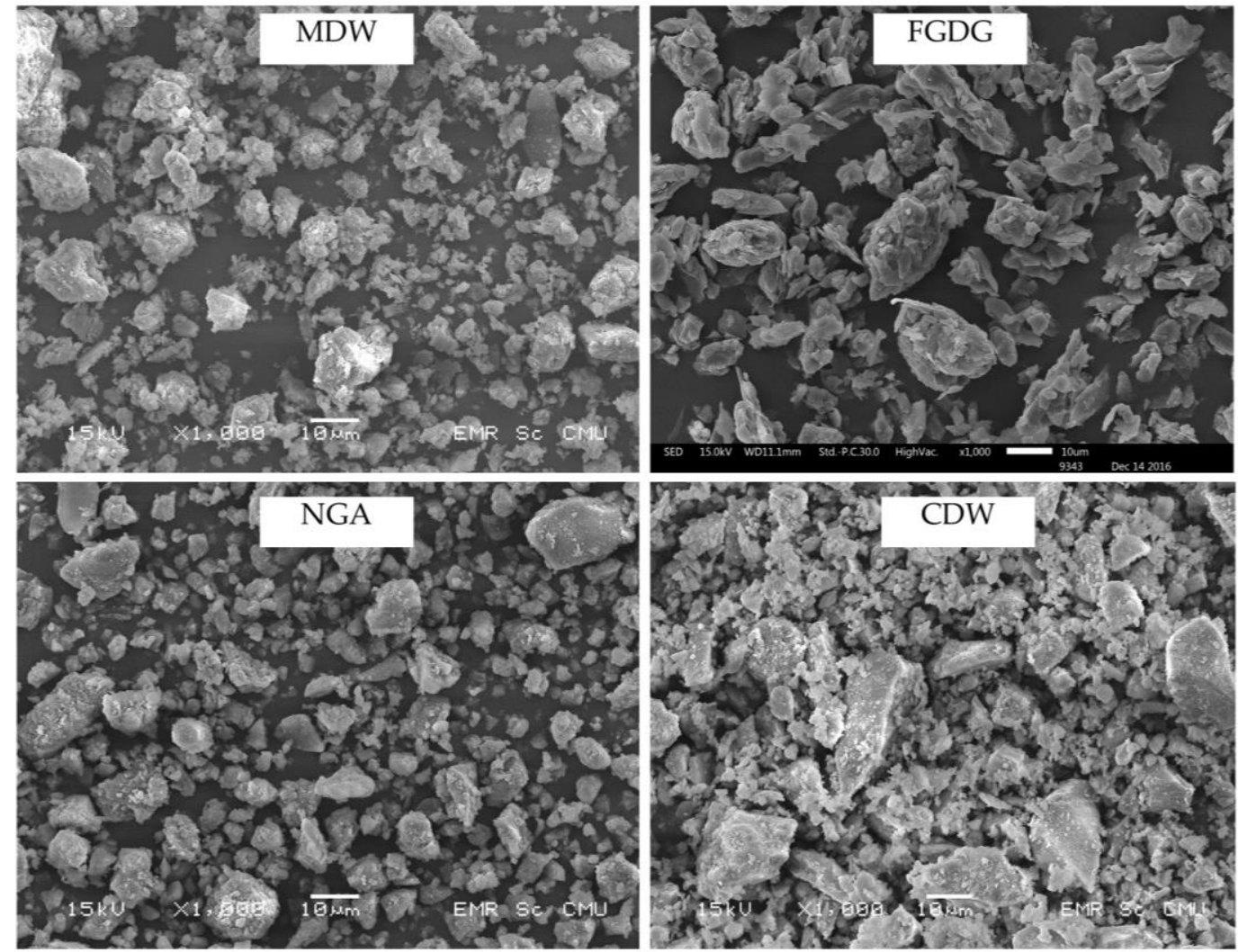

Figure 2. SEM images of the four raw materials used.

\subsection{Characterization of CSA Clinkers}

The target chemical composition of the raw mixture is shown in Table 2. The clinker which was fired at $1250{ }^{\circ} \mathrm{C}$ was chosen for analysis of its chemical composition using the EDXRF technique (Table 2). The chemical composition of the clinker showed slight differences when compared to the target composition due to the inhomogeneity of the waste materials themselves.

Figure 3 illustrates the XRD patterns of CSA clinkers fired at various temperatures. The main phases in all investigated clinkers are ye'elimite and belite, which is consistent with the target phases. However, 
the diffraction patterns of samples fired with various temperatures shows a slight difference, and it is difficult to identify the phases of evolution due to the changing firing temperature. Thus, the changes in phase composition due to increase firing temperature were qualified by the Rietveld analysis and the results are shown in Table 3. For clinker fired at $1200^{\circ} \mathrm{C}$, ye'elimite and belite are dominant phases which are consistent with the target composition. The phase content of ye' elimite and brownmillerite are slightly lower than that of the target phase content while belite is slightly higher. A small amount of unassigned fraction, mayenite and bassanite, was found. By increasing the firing temperature to $1250{ }^{\circ} \mathrm{C}$, the phase content of ye'elimite, belite and brownmillerite was changed and more closely reached the target composition with decreasing of the unassigned fraction. However, an increase of firing temperature to $1300{ }^{\circ} \mathrm{C}$ caused the synthesized clinker showing more difference from the target composition. The firing condition at $1250{ }^{\circ} \mathrm{C}$ for $30 \mathrm{~min}$ was selected to the prepared sample to study the hydration processes.

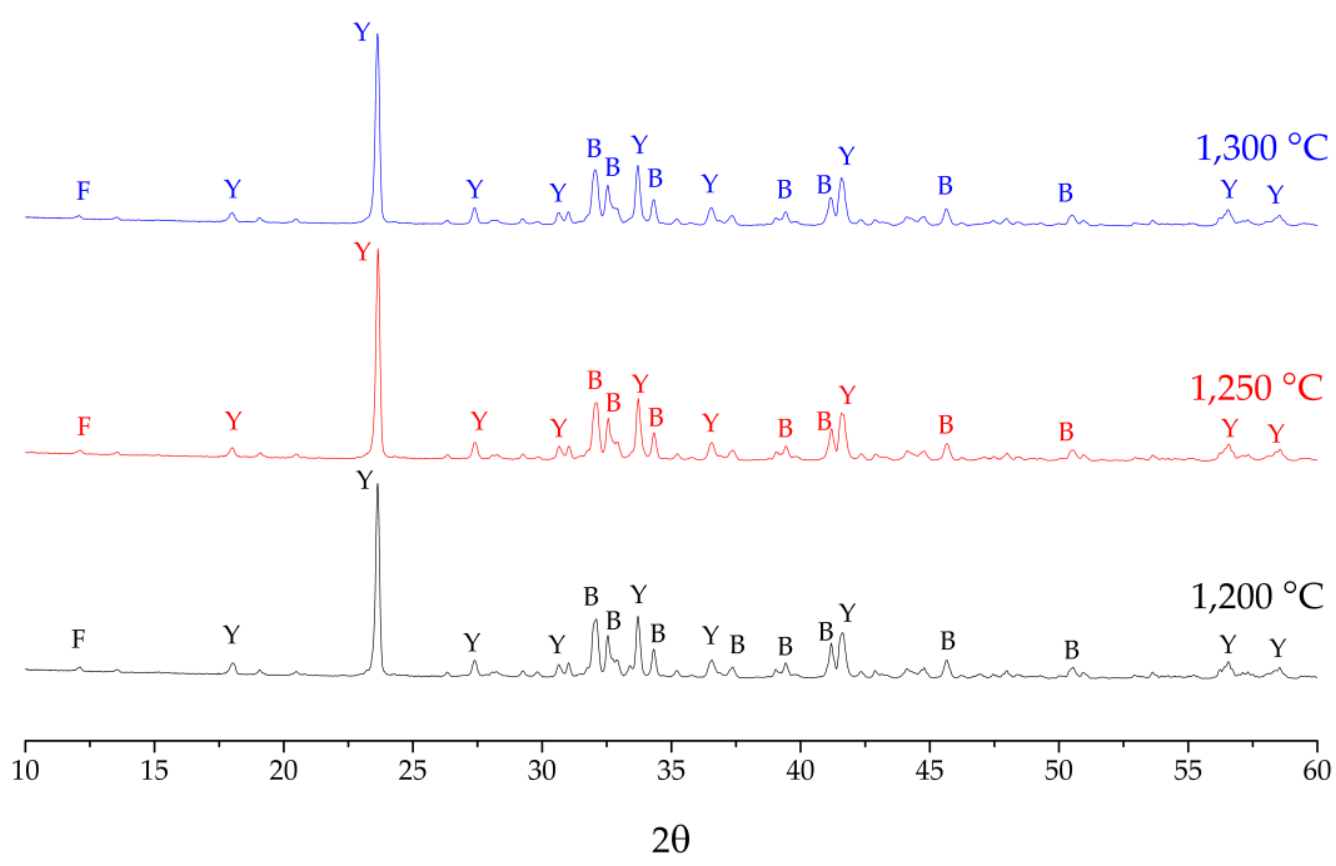

Figure 3. X-ray diffraction patterns of CSA clinkers fired at difference temperatures: $Y=y^{\prime}$ elimite, $\mathrm{B}=$ belite, $\mathrm{F}=$ brownmillerite.

Table 3. Target phase composition of CSA clinker phase and CSA clinker phase composition fired at various temperatures calculated by Rietveld refinement technique.

\begin{tabular}{|c|c|c|c|c|}
\hline Phase & $\begin{array}{c}\text { Target Phase } \\
\text { Composition (wt.\%.) }\end{array}$ & $\begin{array}{c}\text { Clinker Phase } \\
\text { Composition Fired at } \\
1200{ }^{\circ} \mathrm{C}(w t . \% .)\end{array}$ & $\begin{array}{c}\text { Clinker Phase } \\
\text { Composition Fired at } \\
1250^{\circ} \mathrm{C} \text { (wt. } \% \text {.) }\end{array}$ & $\begin{array}{c}\text { Clinker Phase } \\
\text { Composition Fired at } \\
1300^{\circ} \mathrm{C} \text { (wt.\%.) }\end{array}$ \\
\hline Ye'elimite $\left(\mathrm{C}_{4} \mathrm{~A}_{3} \$\right)$ & 50 & 46.25 & 48.11 & 47.41 \\
\hline$\beta$-Belite $\left(\mathrm{C}_{2} \mathrm{~S}\right)$ & 40 & 43.80 & 41.95 & 42.79 \\
\hline Brownmillerite $\left(\mathrm{C}_{4} \mathrm{AF}\right)$ & 10 & 4.54 & 4.90 & 4.36 \\
\hline Mayenite & & 1.50 & 0.07 & 0.36 \\
\hline Bassanite & & 0.25 & 0.05 & 0.27 \\
\hline Good of fitness & & 3.26 & 3.25 & 3.24 \\
\hline
\end{tabular}

\subsection{Characterization of Hydrated Paste}

The clinker was ground and then sieved through $150 \mu \mathrm{m}$ mesh, and subsequently mixed with natural gypsum $\left(\mathrm{CaSO}_{4} \cdot 2 \mathrm{H}_{2} \mathrm{O}\right)$ at a weight ratio of 80:20 to obtain CSA cement. This calcium sulfate $\left(\mathrm{CaSO}_{4} \cdot 2 \mathrm{H}_{2} \mathrm{O}\right)$ content can be transferred into a calcium sulfate to ye'elimite molar ratio (value $\mathrm{M}$ ) of 1.5. According to a formula for calculating the optimum sulfate level for calcium sulfoaluminate cement, a value $\mathrm{M}$ between 0 and 1.5 yields rapid hardening and high strength properties [32,33]. 
When CSA cement is mixed with water, ye'elimite reacts quickly with calcium sulfate and results in the formation of ettringite $\left(\mathrm{C}_{6} \mathrm{~A} \$_{3} \mathrm{H}_{32}\right)$ and aluminum hydroxide $\left(\mathrm{AH}_{3}\right)$ as shown in Equation (1) [27]. The formation of ettringite fills the available space rapidly, providing the paste with good early-age strength [32].

When the calcium sulfate is fully depleted, the hydration of ye'elimite continues with the formation of monosulfate $\left(\mathrm{C}_{4} \mathrm{~A} \$ \mathrm{H}_{12}\right)$ [28], as seen in Equation (2). Theses reactions usually start forming during the age range from $6 \mathrm{~h}$ to $48 \mathrm{~h}$, and the formations of ettringite and monosulfate are strongly influenced by the type and dosage level of calcium sulfate $[34,35]$. Compared with ye'elimite, belite hydrates more slowly. Belite reacts with free water to form calcium silicate hydrates $(\mathrm{C}-\mathrm{S}-\mathrm{H})$ and portlandite $\left(\mathrm{Ca}(\mathrm{OH})_{2}\right)$ as shown in Equation (3). However, the simultaneously hydration reactions of ye'elimite, belite and brownmillerite caused complex reactions to occur. Belite may react with aluminum hydroxide, that is formed by the hydration of ye'elimite, and the main crystalline product is strätlingite $\left(\mathrm{C}_{2} \mathrm{~A} \$ \mathrm{H}_{8}\right)$, as seen in Equation (4), and may be continuously reacting to form hydrogarnet $\left(\mathrm{C}_{3} \mathrm{~A} \$_{\mathrm{x}} \mathrm{H}_{6-2 \mathrm{x}}\right)$, as seen in Equation (5) [32]. On the other hand, calcium hydroxide, mainly generated from the hydration of belite, may be combined with ye'elimite and gypsum, and also generated expansive ettringite as shown in Equation (6) [34].

$$
\begin{gathered}
\mathrm{C}_{4} \mathrm{~A}_{3} \$+2 \mathrm{C} \$+38 \mathrm{H} \rightarrow \mathrm{C}_{6} \mathrm{~A} \$ \mathrm{H}_{32}+2 \mathrm{AH}_{3} \\
C_{4} A_{3} \$+18 H \rightarrow C_{4} A \$ H_{12}+2 A H_{3} \\
C_{2} S+4.3 H \rightarrow C_{1.7} S_{4}+0.3 C H \\
C_{2} S+A H_{3}+5 H \rightarrow C_{2} A \$ H_{8} \\
9 C_{2} S+C_{2} A \$ H_{8} \rightarrow 10 C_{1.7} \$ H_{4}+C_{3} A H_{6} \\
C_{4} A_{3} \$+6 C H+8 C \$+90 H \rightarrow 3 C_{6} A \$ H_{32}
\end{gathered}
$$

Figure 4 shows the FTIR spectra of CSA cement and hydrated pastes at several hydration ages. For anhydrous cement, ye'elimite can be identified by two typical regions. The first one is the $r_{3} \mathrm{SO}^{-2}{ }_{4}$ group vibration peaks centered in 1097 and $1101 \mathrm{~cm}^{-1}$; the second one in the adsorption region, $725-788 \mathrm{~cm}^{-1}$, is interpreted as stretching vibrations of a lattice of $\mathrm{AlO}_{4}$ tetrahedra [36]. The double peak at 870 and $940 \mathrm{~cm}^{-1}$, assigned to Si-O symmetric and antisymmetric stretching of Si-O bonds within tetrahedral $\mathrm{SiO}_{4}$ groups, characterizes mainly $\mathrm{C}_{2} \mathrm{~S}$ phase [37-39]. $\mathrm{C}_{4} \mathrm{AF}$ phase cannot be identified by the FTIR technique due to poorly resolved bands and very small amount. The small peaks at 601 and $669 \mathrm{~cm}^{-1}$ are assigned to the bending modes of sulfate in gypsum. The stretching vibrations of the $\mathrm{H}_{2} \mathrm{O}$ molecules in the gypsum identified by the broad band in the range of $3397-3529 \mathrm{~cm}^{-1}$. The unique peak at $3642 \mathrm{~cm}^{-1}$ and a broad adsorption band site between 1420 and $1590 \mathrm{~cm}^{-1}$ were observed due to the presence of $\mathrm{O}-\mathrm{H}$ stretching and vibration modes $\mathrm{C}-\mathrm{O}$ of carbonate groups, respectively [38]. This suggested portlandite impurity was found and may be caused from natural gypsum contamination. The FTIR spectra of paste hydrated for one day presented a very strong anti-symmetrical centred towards $1120 \mathrm{~cm}^{-1}$, and can be attributed to stretching frequency of $v_{3} \mathrm{SO}^{-2}$ group of ettringite [39]. When considered with the disappearance of a strong peak at $3642 \mathrm{~cm}^{-1}$ due to portlandite, and a broad band in the range of $3397-3529 \mathrm{~cm}^{-1}$ due to gypsum, this suggested that the hydration reaction of ye'elimite following Equation (6) probably occurred. Moreover, an appearance of two small sharp bands with area between 3500 and $3600 \mathrm{~cm}^{-1}$ involves to $\mathrm{C}_{3} \mathrm{AH}_{6}, \mathrm{AH}_{3}$ and $\mathrm{C}_{2} \mathrm{~A} \$ \mathrm{H}_{8}$, which indicated the hydration reaction of $\mathrm{C}_{2} \mathrm{~S}$ according to Equations (4) and (5) probably occurred [36]. After curing for 7 days, the FTIR spectra showed three distinct adsorption bands of ettringite and a very strong anti-symmetrical stretching frequency of the sulphate ion $\left(v_{3} \mathrm{SO}^{-2}{ }_{4}\right)$ centred towards $1120 \mathrm{~cm}^{-1}$. The water absorption band appeared at $1640 \mathrm{~cm}^{-1}$ for $v_{2} \mathrm{H}_{2} \mathrm{O}$ and a broad band at 3420 and $3635 \mathrm{~cm}^{-1}$ due to $v_{1} \mathrm{H}_{2} \mathrm{O}$ and $v \mathrm{OH}_{\text {free, }}$, respectively [39]. A medium sharp at $1660 \mathrm{~cm}^{-1}$ that was assigned to $\mathrm{O}-\mathrm{H}_{\text {capillary }}$ stretching vibrations and two sharp bands at 963 and $985 \mathrm{~cm}^{-1}$ due to $\mathrm{Si}-\mathrm{O}$ 
stretching vibrations of $\mathrm{C}_{1.7} \mathrm{SH}_{4}$. These observations suggested the hydration reaction of ye'elimite and belite.

$168 \mathrm{~h}$
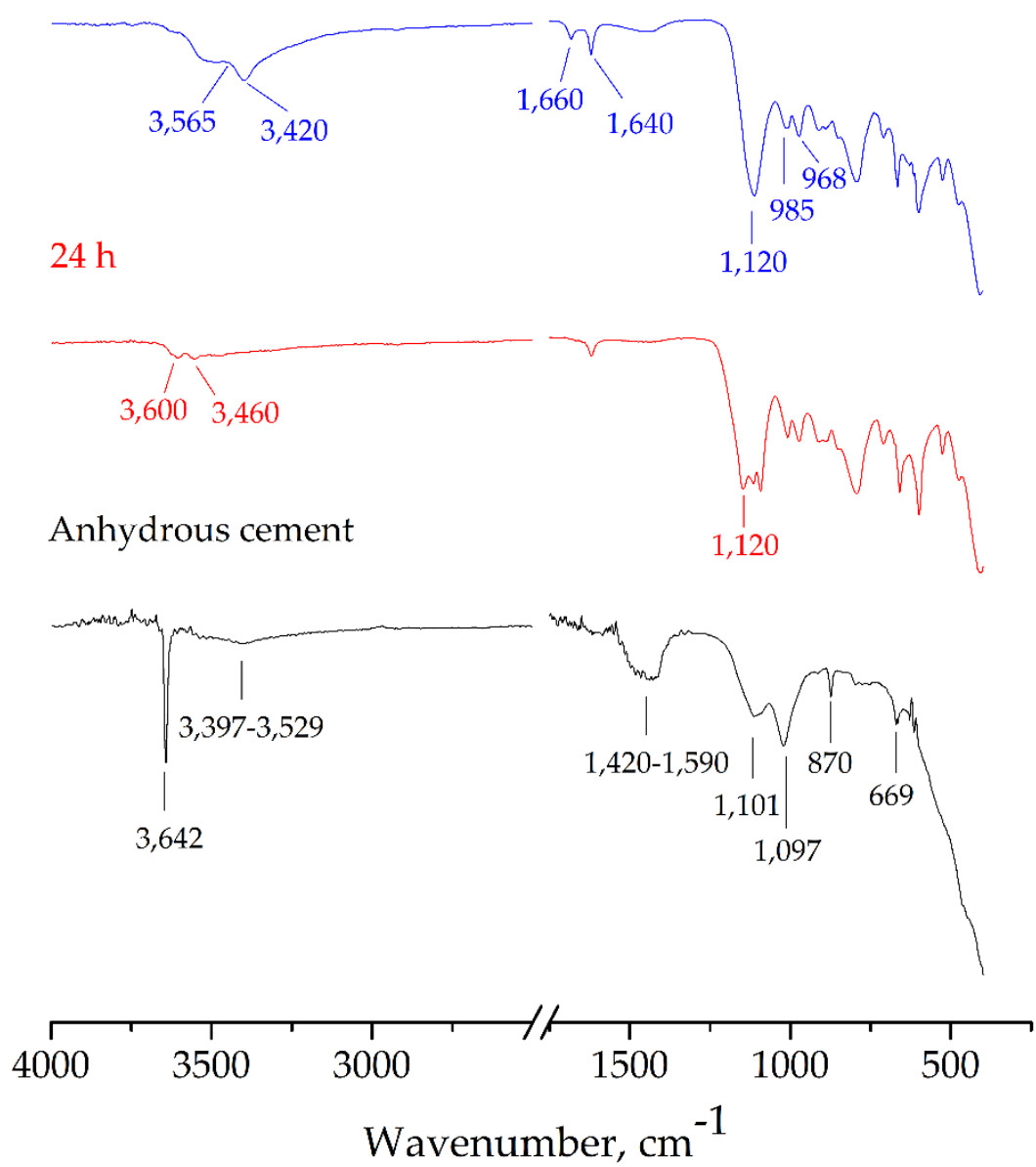

Figure 4. FTIR spectrum of anhydrous cement and hydrated pastes cured for $24 \mathrm{~h}$ and $168 \mathrm{~h}$.

\subsection{Engineering Properties of OPC-CSA Blended Paste}

The CSA cement was mixed together to OPC with various fraction as listed in Table 4. The OPC phase composition, which obtained from the XRD patterns analysis through the Rietveld refinement technique, was shown in Figure 5. When compared to OPC cement, the incorporation of CSA cement leads to an increase in the amount of water required to produce pastes with a desired consistency (Table 4). This can be attributed to the higher amount of the $\mathrm{H}_{2} \mathrm{O}$ molecules needed for hydration of CSA cement when compared to the OPC hydrations. The setting times of cement paste rapidly shortened when the $20 \mathrm{wt} . \%$ of CSA cement was blended to the OPC cement. The initial and final setting times of OPC-CSA blend are gradually shortened by the increase of CSA cement fraction. These can be explained by the higher rate of hydrations of ye'elimite in CSA cement compared to hydration rate of OPC phases [31]. Moreover, the higher water demand during ettringite formation in CSA hydrations is associated with fewer $\mathrm{H}_{2} \mathrm{O}$ molecules and caused the setting times to be shorter [1] 
Table 4. Water to binder ratios $(w / b)$ to normal consistency and setting times of cement pastes.

\begin{tabular}{ccccc}
\hline Sample & $\begin{array}{c}\boldsymbol{\%} \\
\text { CSA }\end{array}$ & $\begin{array}{c}\boldsymbol{w} / \boldsymbol{b} \text { to Normal } \\
\text { Consistency }\end{array}$ & $\begin{array}{c}\text { Initial Setting } \\
\text { Time (minutes) }\end{array}$ & $\begin{array}{c}\text { Final Setting Time } \\
\text { (minutes) }\end{array}$ \\
\hline OPC & 0 & 0.272 & 116 & 195 \\
CSA20 & 20 & 0.318 & 38 & 90 \\
CSA25 & 25 & 0.328 & 28 & 60 \\
CSA30 & 30 & 0.336 & 22 & 55 \\
CSA35 & 35 & 0.369 & 17 & 35 \\
CSA40 & 40 & 0.405 & 17 & 30 \\
\hline
\end{tabular}

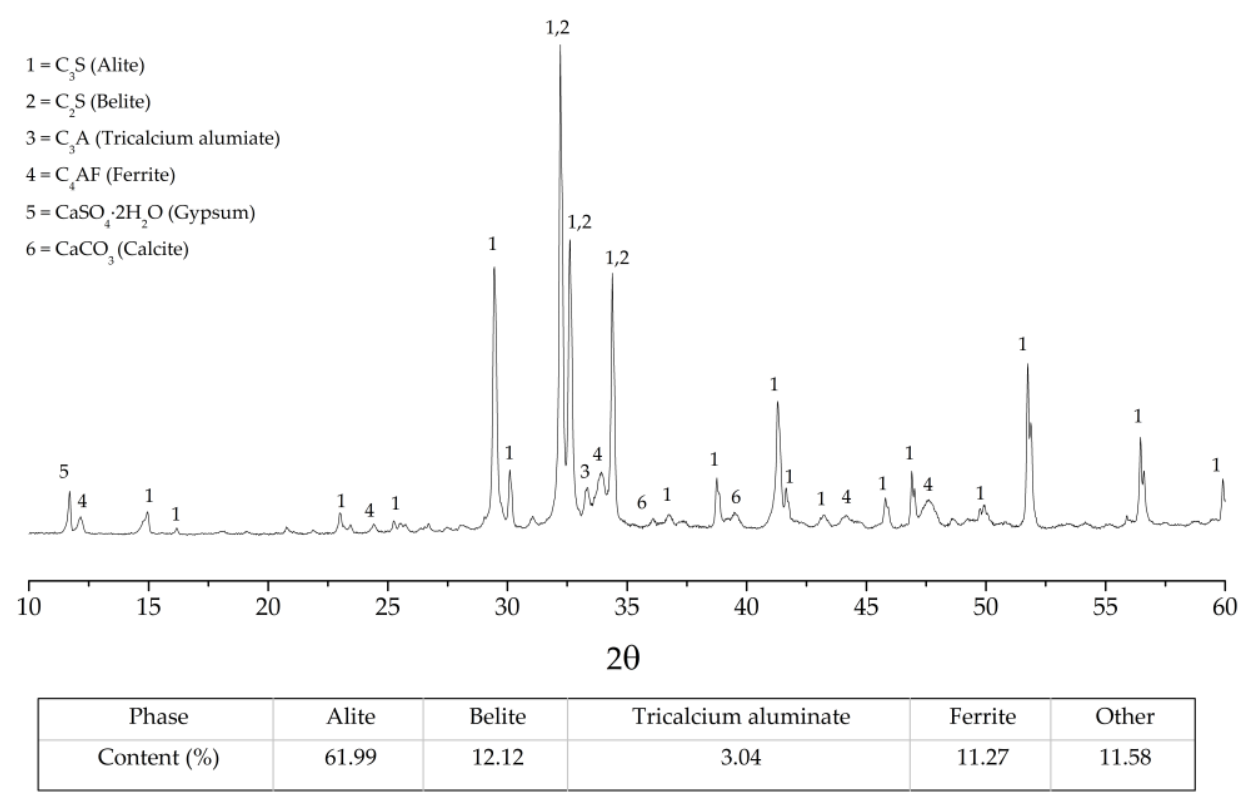

Figure 5. XRD patterns with phase composition of Ordinary Portland cement (OPC).

The effect of CSA cement on the compressive strength of OPC is shown in Table 5. For $6 \mathrm{~h}$ curing period, the compressive strength of OPC paste could not be measured. For OPC-CSA blended, the compressive strength tended to increase with an increase of CSA cement fraction. The CSA40 shows more than 5 times compressive strength when compared to CSA20. These results suggest that the CSA cement is an appropriate admixture to improve early strength of OPC cement. The compressive strength of CSA-OPC blended are mostly higher than OPC paste until a $168 \mathrm{~h}$ curing period. For a longer curing period, the compressive strength of OPC paste is higher than that of all CSA-OPC blended samples. These results correspond to many previous investigations [28,40].

Table 5. Compressive strength of cement pastes at different curing periods.

\begin{tabular}{ccccccccc}
\hline Sample & \% CSA & $\begin{array}{c}\mathbf{6} \mathbf{h} \\
\mathbf{( k s c )}\end{array}$ & $\begin{array}{c}\mathbf{1 2} \mathbf{h} \\
\mathbf{( k s c )}\end{array}$ & $\begin{array}{c}\mathbf{2 4} \mathbf{h} \\
\mathbf{( k s c )}\end{array}$ & $\begin{array}{c}\mathbf{7 2} \mathbf{h} \\
\mathbf{( k s c )}\end{array}$ & $\begin{array}{c}\mathbf{1 6 8} \mathbf{h} \\
\mathbf{( k s c )}\end{array}$ & $\begin{array}{c}\mathbf{3 3 6} \mathbf{h} \\
\mathbf{( k s c )}\end{array}$ & $\begin{array}{c}\mathbf{6 7 2} \mathbf{h} \\
\mathbf{( k s c )}\end{array}$ \\
\hline OPC & 0 & - & 171 & 413 & 519 & 697 & 817 & 850 \\
CSA20 & 20 & 43 & 156 & 310 & 524 & 610 & 627 & 649 \\
CSA25 & 25 & 54 & 212 & 434 & 476 & 549 & 594 & 600 \\
CSA30 & 30 & 59 & 244 & 428 & 444 & 526 & 536 & 582 \\
CSA35 & 35 & 101 & 274 & 439 & 442 & 456 & 481 & 493 \\
CSA40 & 40 & 239 & 305 & 367 & 402 & 424 & 448 & 455 \\
\hline
\end{tabular}

\section{Conclusions}

This study demonstrated the synthesis of calcium sulfoaluminate cement by using several waste materials as raw material. The chemical and mechanical properties of the raw materials, synthesized 
clinker, and hardened synthesized cement paste were studied in detail and the following conclusions were made according to the results of this paper:

- The particular industrial wastes show potential for application as raw material for CSA cement such as marble dust waste, flue gas desulfurization gypsum, and napier grass ash. CSA clinker with desired phase composition (i.e., $\mathrm{C}_{2} \mathrm{~S}, \mathrm{C}_{4} \mathrm{~A}_{3} \$$ and $\mathrm{C}_{4} \mathrm{AF}$ ) can be successfully synthesized with the appropriate mixed proportion.

- CSA clinker fired at $1250{ }^{\circ} \mathrm{C}$ showed most similar phase content compared to designed composition. This clinker was used to study the hydrated pastes at various curing periods by using the FTIR technique.

- The replacement of OPC cement by CSA cement increased the water requirement for normal consistency, and shortened the initial and final setting times.

- Adding of the synthesized CSA cement to OPC cement is very helpful to improve compressive strength in the early age of hydration. However, the long-term compressive strength of synthesized CSA-OPC blended pastes were lower than that of the OPC paste.

Author Contributions: P.J. (Phongthorn Julphunthong), responsible for the overall design of the experiment and the writing of manuscripts; P.J. (Panuwat Joyklad), responsible for the experimental guidance and data collection and analysis.

Funding: This work was financially supported by Naresuan University (R2559B090).

Acknowledgments: Thanks also to the Department of Civil Engineering, Faculty of Engineering, Naresuan University for supporting facilities. The authors also express our gratitude to the Siam City Cement Public Company Limited for their support and material characterizations. Acknowledgement also to Paul Freund of Naresuan University Writing Clinic (DIALD) for helpful comments and corrections of the manuscript.

Conflicts of Interest: The authors declared that have no conflicts of interest to this work. We declare that we do not have any commercial or associative interest that represents a conflict of interest in connection with the work submitted. We declare that the funding agency does not affect the submission of manuscripts.

\section{References}

1. Ioannou, S.; Reig, L.; Paine, K.; Quillin, K. Properties of a ternary calcium sulfoaluminate-calcium sulfate-fly ash cement. Cem. Concr. Res. 2014, 56, 75-83. [CrossRef]

2. Zhang, L.; Su, M.Z.; Wang, Y.M. Development of the use of sulfo- and ferroaluminate cements in China. Adv. Cem. Res. 1999, 11, 15-21. [CrossRef]

3. Gartner, E. Are there any practical alternatives to the manufacture of Portland cement clinker? In Proceedings of the 11th International Conference on Non-conventional Materials and Technologies NOCMAT, Bath, UK, 6-9 September 2009; University of Bath: Bath, UK, 2009.

4. Hanein, T.; Elhoweris, A.; Galan, I.; Glasser, F.P.; Campbell Bannerman, M.N. Thermodynamic data of ye'elemite $\left(\mathrm{C}_{4} \mathrm{~A}_{3} \$\right)$ for cement clinker equilibrium calculations. In Proceedings of the 35th Cement \& Concrete Science Conference, Aberdeen, UK, 26-28 August 2015; University of Aberdeen: Aberdeen, UK, 2015.

5. Wang, J.; Baco, I.; Morin, V.; Walenta, G.; Damidot, D.; Gartner, E. Hydration mechanism of cements based on low- $\mathrm{CO}_{2}$ clinkers containing belite, ye'elimite and calcium alumino-ferrite. In Proceedings of the 7th International Symposium on Cement \& Concrete, Jinan, China, 9-12 May 2010; Foreign Languages Press: Beijing, China, 2010.

6. Galan, I.; Glasser, F.P.; Elhoweris, A.; Tully, S.; Murdoch, A. Novel process for calcium sulfoaluminate cement production. In Proceedings of the 34th Cement and Concrete Science Conference, Sheffield, UK, 14-17 September 2014; University of Sheffield: Sheffield, UK, 2014.

7. Sharp, J.H.; Lawrence, C.D.; Yang, R. Calcium sulfoaluminate cements-Low-energy cements, special cements or what? Adv. Cem. Res. 1999, 11, 3-13. [CrossRef]

8. Georgin, J.; Ambroise, J.; Pera, J.; Reynouard, J. Development of self-leveling screed based on calcium sulfoaluminate cement: Modelling of curling due to drying. Cem. Concr. Compos. 2008, 30, 769-778. [CrossRef]

9. Winnefeld, F.; Lothenbach, B. Hydration of calcium sulfoaluminate cements-Experimental findings and thermodynamic modelling. Cem. Concr. Res. 2010, 40, 1239-1247. [CrossRef] 
10. Sirtoli, D.; Wyrzykowski, M.; Riva, P.; Tortelli, S.; Marchi, M.; Lura, P. Shrinkage and creep of high-performance concrete based on calcium sulfoaluminate cement. Cem. Concr. Compos. 2019, 98, 61-73. [CrossRef]

11. Glasser, F.; Zhang, L. High-performance cement matrices based on calcium sulfoaluminate-belite compositions. Cem. Concr. Res. 2001, 31, 1881-1886. [CrossRef]

12. Mehdipour, I.; Khayat, K.H. Enhancing the performance of calcium sulfoaluminate blended cements with shrinkage reducing admixture or lightweight sand. Cem. Concr. Compos. 2018, 87, 29-43. [CrossRef]

13. Al Horr, Y.; Elhoweris, A.; Elsarrag, E. The development of a novel process for the production of calcium sulfoaluminate. Int. J. Sustain. Built Environ. 2017, 6, 734-741. [CrossRef]

14. Chen, I.A.; Hargis, C.W.; Juenger, M.C. Understanding expansion in calcium sulfoaluminate-belite cements. Cem. Concr. Res. 2012, 42, 51-60. [CrossRef]

15. Jeong, Y.; Hargis, C.W.; Chun, S.; Moon, J. Effect of Calcium Carbonate Fineness on Calcium Sulfoaluminate-Belite Cement. Materials 2017, 10, 900. [CrossRef] [PubMed]

16. Jeong, Y.; Hargis, C.W.; Chun, S.-C.; Moon, J. The effect of water and gypsum content on strätlingite formation in calcium sulfoaluminate-belite cement pastes. Constr. Build. Mater. 2018, 166, 712-722. [CrossRef]

17. Schneider, M.; Romer, M.; Tschudin, M.; Bolio, H. Sustainable cement production-Present and future. Cem. Concr. Res. 2011, 41, 642-650. [CrossRef]

18. Zhang, X.; Zhao, M.; Zhang, Y. Preparation and properties of self-pulverizing calcium sulfoaluminate cement. Constr. Build. Mater. 2012, 34, 107-113. [CrossRef]

19. Juenger, M.; Winnefeld, F.; Provis, J.; Ideker, J. Advances in alternative cementitious binders. Cem. Concr. Res. 2011, 41, 1232-1243. [CrossRef]

20. Gartner, E. Industrially interesting approaches to “low-CO2" cements. Cem. Concr. Res. 2004, 34, 1489-1498. [CrossRef]

21. Chen, I.A.; Juenger, M.C. Incorporation of coal combustion residuals into calcium sulfoaluminate-belite cement clinkers. Cem. Concr. Compos. 2012, 34, 893-902. [CrossRef]

22. Bouregba, A.; Elghattas, B.; Guedira, T. Influence of Fluorine on Clinker burnability and mechanical properties of CPA Moroccan cement. MATEC Web Conf. 2018, 149, 01075. [CrossRef]

23. Djerdi, I. Rietveld Refinement in the Characterization of Crystalline Materials, Printed Edition of the Special Issue Published in Crystals; MDPI: Basel, Switzerland, 2019; pp. 1-11.

24. Le Saoût, G.; Kocaba, V.; Scrivener, K. Application of the Rietveld method to the analysis of anhydrous cement. Cem. Concr. Res. 2011, 41, 133-148. [CrossRef]

25. Chaunsali, P.; Mondal, P. Physico-chemical interaction between mineral admixtures and OPC-calcium sulfoaluminate (CSA) cements and its influence on early-age expansion. Cem. Concr. Res. 2016, 80, 10-20. [CrossRef]

26. Trauchessec, R.; Mechling, J.-M.; LeComte, A.; Roux, A.; Le Rolland, B. Hydration of ordinary Portland cement and calcium sulfoaluminate cement blends. Cem. Concr. Compos. 2015, 56, 106-114. [CrossRef]

27. Telesca, A.; Marroccoli, M.; Pace, M.; Tomasulo, M.; Valenti, G.; Monteiro, P. A hydration study of various calcium sulfoaluminate cements. Cem. Concr. Compos. 2014, 53, 224-232. [CrossRef]

28. Yeung, J.S.; Yam, M.C.; Wong, Y. 1-Year development trend of concrete compressive strength using Calcium Sulfoaluminate cement blended with OPC, PFA and GGBS. Constr. Build. Mater. 2019, 198, 527-536. [CrossRef]

29. ASTM C187-16, Standard Test Method for Amount of Water Required for Normal Consistency of Hydraulic Cement Paste; ASTM International: West Conshohocken, PA, USA, 2016.

30. ASTM C191-19, Standard Test Methods for Time of Setting of Hydraulic Cement by Vicat Needle; ASTM International: West Conshohocken, PA, USA, 2019.

31. Rungchet, A.; Poon, C.; Chindaprasirt, P.; Pimraksa, K. Synthesis of low-temperature calcium sulfoaluminatebelite cements from industrial wastes and their hydration: Comparative studies between lignite fly ash and bottom ash. Cem. Concr. Compos. 2017, 83, 10-19. [CrossRef]

32. Li, C.; Wu, M.; Yao, W. Effect of coupled B/Na and B/Ba doping on hydraulic properties of beliteye'elimite-ferrite cement. Constr. Build. Mater. 2019, 208, 23-35. [CrossRef]

33. Winnefeld, F.; Barlag, S. Calorimetric and thermogravimetric study on the influence of calcium sulfate on the hydration of ye'elimite. J. Therm. Anal. Calorim. 2010, 101, 949-957. [CrossRef]

34. Cuesta, A.; Álvarez-Pinazo, G.; Sanfélix, S.; Peral, I.; Aranda, M.A.; De La Torre, A.; Alonso, I.P. Hydration mechanisms of two polymorphs of synthetic ye'elimite. Cem. Concr. Res. 2014, 63, 127-136. [CrossRef] 
35. Álvarez-Pinazo, G.; Santacruz, I.; Aranda, M.A.G.; De La Torre, Á.G. Hydration of belite-ye'elimite-ferrite cements with different calcium sulfate sources. Adv. Cem. Res. 2016, 28, 1-15. [CrossRef]

36. Tang, S.; Zhu, H.; Li, Z.; Chen, E.; Shao, H. Hydration stage identification and phase transformation of calcium sulfoaluminate cement at early age. Constr. Build. Mater. 2015, 75, 11-18. [CrossRef]

37. Horgnies, M.; Chen, J.J.; Bouillon, C. Overview about the use of Fourier transform infrared spectroscopy to study cementitious materials. In Proceedings of the 6th International Conference on Computational Methods and Experiments in Materials Characterization, Siena, Italy, 4-6 June 2013; WIT Transactions on Engineering Sciences: Southampton, UK, 2013; pp. 251-262.

38. Khachani, M.; El Hamidi, A.; Halim, M.; Arsalane, S. Non-isothermal kinetic and thermodynamic studies of the dehydroxylation process of synthetic calcium hydroxide $\mathrm{Ca}(\mathrm{OH})_{2}$. J. Mater. Environ. Sci. 2014, 5, 615-624.

39. Fernndez-Carrasco, L.; Torrens-Martn, D.; Morales, L.; Martnez-Ramrez, S.; Fernández-Carrasco, D.T.-M.L. Infrared Spectroscopy in the Analysis of Building and Construction Materials. In Infrared SpectroscopyMaterials Science, Engineering and Technology; IntechOpen: London, UK, 2012; pp. 369-382.

40. Zhang, J.; Li, G.; Yang, X.; Ren, S.; Song, Z. Study on a high strength ternary blend containing calcium sulfoaluminate cement/calcium aluminate cement/ordinary Portland cement. Constr. Build. Mater. 2018, 191, 544-553. [CrossRef]

(C) 2019 by the authors. Licensee MDPI, Basel, Switzerland. This article is an open access article distributed under the terms and conditions of the Creative Commons Attribution (CC BY) license (http://creativecommons.org/licenses/by/4.0/). 